\title{
The Carnegie Corporation Advisory Group on Canadian College Libraries, 1930-35
}

\author{
Lorne D. Bruce
}

McLaughlin Library, University of Guelph

\section{ABSTRACT}

The Carnegie Corporation of New York (CCNY) contributed significantly to the development of Canadian university and college libraries during the Great Depression. From 1932 to 1935, thirty-four institutions of higher education shared in library book grants totalling $\$ 214,800$ as a result of a national (Canada and Newfoundland) examination conducted by an advisory group established by the CCNY. The ways in which the advisory group investigated and inspected potential recipients, evaluated whether they complied with conditions set, and distributed grants typically followed the policies and procedures established by an earlier American advisory group funded by the CCNY. Carnegie and university records document how financial aid was awarded and used for the advancement of undergraduate print collections. Sources can also be used to study the Canadian group in relation to the role of American philanthropic college library work, attempts by Canadian administrators to adapt library collections and organization to local circumstances, and trends in the improvement of undergraduate library services on a national scale.

RÉSUMÉ

L'organisme The Carnegie Corporation of New York (CCNY) a contribué d'une manière significative au développement des bibliothèques des universités et des collèges canadiens durant la grande dépression. De 1932 à 1935, trente-quatre institutions d'éducation supérieure se sont partagé des octrois totalisant 214800 \$ pour l'achat de livres. Ce montant a été établi lors d'une enquête nationale menée conjointement au Canada et à Terre-Neuve par un groupe de travail consultatif établi par le CCNY. Les manières de procéder de ce comité quant à l'investigation et à la surveillance des institutions récipiendaires, l'évaluation du respect des conditions fixées ainsi que la distribution des subventions s'appuient sur les politiques et procédures établies précédemment par un comité consultatif américain créé par le CCNY. Les documents provenant de la corporation Carnegie et des universités exposent comment l'aide financière était accordée et utilisée pour l'enrichissement des collections des imprimés pour les étudiants du premier cycle. Ces sources peuvent aussi servir à étudier les relations du groupe canadien avec la philanthropie américaine en regard des bibliothèques. D'autres questions comme les tentatives des administrateurs canadiens pour harmoniser les collections des bibliothèques et les adapter aux besoins spécifiques de leur milieu, ainsi que la tendance à améliorer les services fournis par les bibliothèques aux étudiants de premier cycle à l'échelle canadienne, pourraient faire l'objet d'études ultérieures. 
In 1930, the Carnegie Corporation of New York (CCNY) funded a commission of inquiry headed by John Ridington, university librarian at the University of British Columbia, to survey the state of all Canadian libraries. The commission's report, Libraries in Canada, published in 1933, included a sober chapter on university libraries. Ridington lamented that universities returned only fifteen of twenty-three questionnaires distributed, library data was often incomplete, and extensive variations in academic collections, services, financing, and staffing precluded general assessments. He surmised that some universities considered the library to be the proverbial "heart of the university" whereas others were "content to give lectures, to hold examinations, and grant degrees without exposing their students to any risk of contact with books, outside the texts prescribed for the course taken." "The report on university libraries suggested that the library's role on Canadian campuses was a random mingling of ideas emanating from denominational origins, geographical settings, governing boards, senates, administrators, library committees, faculty, students, alumni, donors, and a small corps of trained librarians.

The historiography of Canadian Carnegie library programs in the first half of the twentieth century (which sometimes dovetailed with Rockefeller Foundation programs) has emphasized the powerful influence of American philanthropy in Canada on a broad scale, notably through the erection of public libraries, the formation of a national library association, the expansion of professional library education, regional library development, and the encouragement of library practices and ideas grounded in American patterns. ${ }^{2}$ However, one episode in the history of Carnegie philanthropy is seldom mentioned: the work of an Advisory Group on Canadian College Libraries formed in 1931. General historical library overviews and even individual histories of university libraries have paid scant attention to this book stimulus program that dispensed $\$ 214,800$ to thirty-four university and college libraries between 1933 and 1935. ${ }^{3}$ Most library histories begin with the post-1945 period or even later, in the early 1960s. ${ }^{4}$ Two reasons may account for this neglect. First, the advisory group's activity was outside the usual framework of philanthropic work described in our histories. The Carnegie book awards primarily helped to alert university officials to the value of a good library, to augment local collections for undergraduates, and to promote the library's potential as a partner with faculty. These aims were less tangible than buildings or new organizations and were fated to dissipate over a short time span. Second, our sources are scattered by geography and most contribute partial information to the overall record of the advisory group. The Carnegie Corporation records at Columbia University are the major resource that documents the group's lifespan and its interactions with individual Canadian institutions. Canadian university records add somewhat to our knowledge, as does correspondence held at the University of Michigan. Unfortunately, records for the advisory group's chair, George Locke, have not survived at the Toronto Public Library, where he was chief librarian. Other contemporary sources — student campus newspapers, official university publications, alumni news, college yearbooks, and the press - provide information on local responses, especially for students, who were the main beneficiaries of the Carnegie book awards. All these records are examined in this paper to describe and analyze 
the advisory group's activity, its place in university library history, and the state of college libraries during the depths of the Great Depression. The Carnegie effort to accentuate library service in the United States and Canada was an important stimulus towards undergraduate education by augmenting collections, aligning with new ideas about instruction for courses, and supporting more informed professional practices.

\section{University and College Library Conditions in 1930}

Generally, the onset of the Great Depression speedily dampened hopes for immediate improvements to university or college collections, buildings, or professional staffing across Canada. The unenthusiastic, Depression-related comments in Libraries in Canada about the standing of libraries in higher education was accompanied at the local level by intermittent efforts by students to improve study and reading. A year and a half after the issue of Sunday library openings was first raised by students in the University of Toronto's paper, The Varsity, in the fall of 1928, W. Stewart Wallace, Toronto's university librarian, replied,

As there has never been any student demand, the necessity of keeping the university library open on Sunday has never been considered... I have an open mind about the matter, but I am rather dubious as to the number of students who would make use of the library on Sundays. ${ }^{5}$

Sunday openings would have to wait, and tiresome checkout lineups at the University of Toronto's main library late Saturday afternoon would continue. At McGill, student editors complained about "library pests" — inconsiderate students who talked loudly in the overcrowded work spaces, or other selfish monopolizers who practised "ganging" - passing on forty-eight-hour reading list books directly to friends to be re-borrowed. ${ }^{6}$ Students at Alberta had to postpone expectations for a new library building and be content with the installation of an oxygen converter to improve ventilation in study areas. ${ }^{7}$ Predictably, in smaller colleges geared to offering advanced courses leading to degrees with an affiliated university, such as Assumption, Waterloo, Mount Royal, and Victoria (BC), the library premises, staff, and collections were understandably underdeveloped. At Prince of Wales College, Charlottetown, the situation was more disheartening: students complained that they were handicapped by the very absence of a library and reading room. ${ }^{8}$

In fairness to the Toronto, McGill, and Alberta library directors-W. Stewart Wallace, Gerhard R. Lomer, and Donald E. Cameron respectively-economic challenges and competing departmental campus projects were overwhelming matters raised in student newspapers. Wallace was preparing a key report promoting that a substantial extension of the original 1892 main campus library be built. Although the building had been expanded in 1910, he asserted that its facilities were now "sadly behind the times." His goal would continue to be stymied for another quarter-century until the Sigmund Samuel Wing opened in 1954, the year Wallace retired. Lomer was immersed in supervising day-to-day activity in the congested Redpath Library, in 
arranging suitable accommodation and access for the extensive Gest Chinese Research Library acquired in 1926, and in establishing the first Canadian graduate program in librarianship after 1927, the latter assisted by the Carnegie Corporation. ${ }^{10}$ Cameron was preparing plans (as he often did) for the merger of dispersed collections in a new main library, one that eventually opened in 1951, six years after his retirement. ${ }^{11}$

Across the country, other library administrators struggled with financial austerity and overextended operations. For example, Fred Landon (University of Western Ontario) and Mary Kinley Ingraham (Acadia) were actively involved in teaching duties and university extension work. Landon, also an active historian, was beginning to make his mark in librarianship, having served as president of the Ontario Library Association in 1926-27. ${ }^{12}$ Western's general library, which had been housed in the west wing of the University College of Arts since 1924, was crowded with books and hampered by the location of its study space in the basement (see Figure 1); accordingly, a separate building was becoming a requisite. Mary Ingraham was busy teaching courses on library methods as part of a bachelor of arts program and helping launch Acadia's bookmobile service to Maritime communities in $1930 .^{13}$

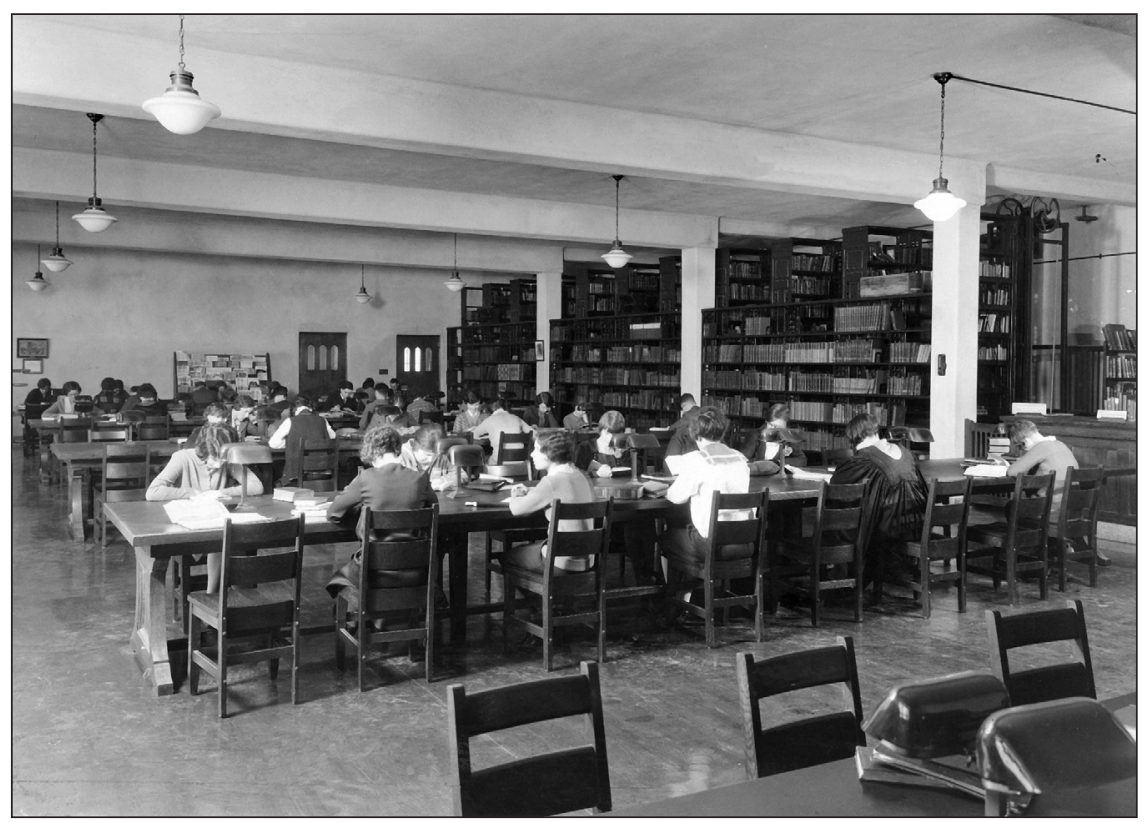

Figure 1. Western's Reading Room, Arts Building basement, 1927. "Way We Were Collection," AFC 363-S6. Photo courtesy of Western Archives, Western University.

Data collected biennially by the Dominion Bureau of Statistics (DBS), especially the published survey reports for 1931, revealed the embryonic condition of many library collections on Canadian campuses that Libraries in Canada had explored. According to the DBS figures drawn from two reports published in 1931, library holdings increased in the range of 55 to 70 per cent between 1925 and 1931 (Table 1). ${ }^{14}$ Usually, 
collections were modest and not research-intensive: in 1931 only seven libraries reported more than 75,000 volumes; five reported more than 500 journal subscriptions; and six expended more than $\$ 10,000$ on books and journals for the entire year. McGill, Queen's, Toronto, Western, and British Columbia were at the forefront. Collectively, in 1931, the twenty-three reporting libraries spent less than $\$ 175,000$ on materials and purchased fewer than 10,000 journal subscriptions. The information on circulation and staffing that John Ridington reported on for 1930-31 was incomplete or missing in many instances, but provides a more detailed portrayal for eleven libraries:

- Acadia: 4 staff, all trained; 6,252 overnight loans

- Dalhousie: 6 staff (3 are student assistants)

- Mount Allison: 3 trained staff, 4 students; 2,801 overnight and 1,294 in-house loans

- McGill: 52 staff (35 professionally trained); 102,500 circulation

- Western: 12 staff (7 professionally trained); 50,000 circulation

- Queen's: 18 full-time assistants; 60,000 home study circulation

- McMaster: 4 staff (2 professionally trained); 29,000 home and reading room loans

- Toronto: 262,103 circulations (117,000 are overnight loans)

- Victoria University, Toronto: 7 staff (2 are part-time)

- Saskatchewan: 1 professional librarian and 6 staff (2 professionally trained)

- British Columbia: 10 staff (5 professionally trained); 105,000 15

Of course, collections and personnel did not alone determine the calibre of library service. From his analysis of available data, Ridington concluded that further study would be necessary to develop a national perspective.

Table 1

Canadian Library College Statistics, 1925-1931

\begin{tabular}{|c|c|c|c|c|c|c|}
\hline University & $\begin{array}{c}\text { Vols held } \\
1925^{1}\end{array}$ & $\begin{array}{l}\text { Vols held } \\
1930-31^{2}\end{array}$ & $\begin{array}{c}\text { Journal } \\
\text { titles } \\
\text { received } \\
1930-31^{2}\end{array}$ & $\begin{array}{c}\text { Volumes } \\
\text { held } \\
1931^{3}\end{array}$ & $\begin{array}{c}\text { Journal } \\
\text { titles } \\
\text { received } \\
1931^{3}\end{array}$ & $\begin{array}{c}\text { Annual } \\
\text { expense } \\
\text { on bks } \\
\text { and jrnls } \\
1931^{3}\end{array}$ \\
\hline St. Dunstan's & 3,100 & 6,350 & - & 6,127 & 22 & $\$ 153$ \\
\hline Acadia & 47,000 & 60,906 & 195 & 60,400 & 185 & $\$ 2,787$ \\
\hline Dalhousie & 72,000 & 90,814 & 378 & 84,006 & 180 & $\$ 6,800$ \\
\hline King's College & 26,000 & 20,000 & - & 18,000 & - & - \\
\hline St. Francis Xavier & 30,000 & 44,000 & 40 & 43,250 & 43 & $\$ 737$ \\
\hline Mount Allison & 16,000 & 37,400 & 104 & 32,196 & 192 & $\$ 6,969$ \\
\hline New Brunswick & 14,000 & 20,000 & 25 & 25,000 & 60 & $\$ 636$ \\
\hline
\end{tabular}




\begin{tabular}{|c|c|c|c|c|c|c|}
\hline University & $\begin{array}{c}\text { Vols held } \\
1925^{1}\end{array}$ & $\begin{array}{l}\text { Vols held } \\
1930-31^{2}\end{array}$ & $\begin{array}{c}\text { Journal } \\
\text { titles } \\
\text { received } \\
1930-31^{2}\end{array}$ & $\begin{array}{l}\text { Volumes } \\
\text { held } \\
1931^{3}\end{array}$ & $\begin{array}{c}\text { Journal } \\
\text { titles } \\
\text { received } \\
1931^{3}\end{array}$ & $\begin{array}{c}\text { Annual } \\
\text { expense } \\
\text { on bks } \\
\text { and jrnls } \\
1931^{3}\end{array}$ \\
\hline St. Joseph's & 10,000 & 16,000 & - & 20,000 & 30 & $\$ 600$ \\
\hline Bishop's & 10,000 & 16,000 & 20 & 20,000 & 12 & $\$ 700$ \\
\hline McGill & 241,662 & 400,000 & 1,500 & 450,000 & 1,600 & $\$ 30,202$ \\
\hline Montreal* & 128,000 & - & - & - & - & - \\
\hline Laval** & - & 247,391 & - & 143,656 & 413 & $\$ 2,000$ \\
\hline Ottawa & 30,000 & 80,000 & - & 61,100 & 200 & $\$ 3,500$ \\
\hline $\begin{array}{l}\text { Western } \\
\text { Ontario }\end{array}$ & 135,000 & 95,518 & 754 & 100,888 & 950 & $\$ 10,593$ \\
\hline Queen's & - & 136,675 & 790 & 143,092 & 760 & $\$ 10,380$ \\
\hline McMaster & 26,000 & 32,500 & 175 & 32,967 & 189 & $\$ 2,999$ \\
\hline Toronto*** & 203,777 & 357,682 & 2,000 & 275,827 & 3,000 & $\$ 50,000$ \\
\hline Trinity College & 30,000 & 35,000 & 30 & 30,921 & 37 & $\$ 1,500$ \\
\hline $\begin{array}{l}\text { Victoria } \\
\text { University, } \\
\text { Toronto }\end{array}$ & - & 48,140 & 166 & 46,000 & - & - \\
\hline Manitoba & 39,000 & 67,460 & 825 & 52,000 & 440 & 6,996 \\
\hline Saskatchewan & 32,000 & 53,000 & 400 & 55,262 & 296 & $\$ 5,855$ \\
\hline Alberta & 30,000 & 43,675 & 445 & 45,000 & 450 & $\$ 12,000$ \\
\hline British Columbia & 43,000 & 90,000 & 550 & 80,047 & 686 & $\$ 13,478$ \\
\hline Totals & $1,166,539$ & $1,998,511$ & 8,397 & $1,825,739$ & 9,745 & $\$ 168,885$ \\
\hline $\begin{array}{l}\text { Per cent } \\
\text { increase in } \\
\text { volumes } \\
\text { 1925-31 }\end{array}$ & & $71.3 \%$ & & $56.5 \%$ & & \\
\hline
\end{tabular}

* Montreal's main library was destroyed by fire.

* Laval's 1931 book total did not include 50,398 pamphlets.

*** Toronto's 1931 central university book total did not include 100,571 pamphlets.

Sources

1 DBS, Annual Survey of Education in Canada in 1925 (Ottawa, 1926).

2 DBS, Annual Survey of Education in Canada in 1931 (Ottawa, 1932).

3 DBS, Survey of Libraries in Canada 1931 (Ottawa, 1933).

Contemporary changes in accommodation also contributes to our knowledge about the state of libraries outlined by Ridington and the DBS surveys. The development of new structures, additions, and renovations offered opportunities to organize holdings, staff, and users in more efficient arrangements. British Columbia's main library on the Point Grey campus (1925) and the Douglas Library at Queen's (1924) were prominent buildings that served as models for planning prior to the Second World 
War. One architect judged the Douglas building to be "the most modern and complete of any University library in Canada." 16 At the end of the 1920s there was an upsurge in library construction: six smaller libraries were completed to enhance accommodation for books and users. The Mount Allison Memorial Library, erected in 1927, could hold 60,000 books and had a spacious reading room. ${ }^{17}$ The Leonard Library, Wycliffe College, formally opened in 1930; it was designed to house 30,000 volumes in its stack area and 6,000 more for theological students in a second floor reading room. ${ }^{18}$ New Brunswick's main library, funded with $\$ 100,000$ from the provincial government, opened in $1931 .{ }^{19}$ With financial assistance from the Carnegie Corporation, the University of King's College was relocated adjacent to Dalhousie University campus by 1930 and its library of 25,000 volumes and reading room was housed on the third floor of the new Arts and Administration building. ${ }^{20}$ When McMaster moved to Hamilton to fields donated by the Royal Botanical Gardens Society in 1930, the library was located in a wing of University Hall. ${ }^{21}$ This was a standard arrangement for smaller libraries and applied to a third-floor library in Toronto's new Emmanuel College (1931). However, progress was not universal. Fires in the early 1920s at the University of Montreal had led to an agreement to allow students to use the main floor of Saint-Sulpice library, an arrangement suspended when the Sulpician order closed the library due to financial exigency in summer $1931 .^{22}$ From the standpoint of physical library facilities, the first decade of the interwar period had been an active period of advancement on many Canadian campuses.

The growth of collections and better facilities drew attention to the need for additional trained personnel with higher educational qualifications and for continuing education in librarianship. Library schools at McGill and Toronto, as well as American schools, were beginning to supply the emergent Canadian library profession with younger, university-educated graduates after $1930 .{ }^{23}$ But in the workplace, there were limited opportunities for professional development, personal growth in librarianship, or academic pursuits. Several provinces had formed provincial library associations, but their memberships were small and often preoccupied with public library issues. From time to time, the Ontario Library Association (OLA) held special college and reference round tables at its annual meetings in Toronto. In 1930, Fred Landon led an OLA session on bibliographical work and the Canadian Periodical Index, which the Western library supported by mimeographing a listing of the contents of a few periodicals and mailing copies to libraries at a charge of 50 cents. ${ }^{24}$ The Ontario Regional Group of Cataloguers, affiliated with the American Library Association (ALA), organized its annual meetings in concert with the OLA. ${ }^{25}$ However, college library concerns were not formally recognized by the OLA before the Reference Workshop Section came into being in $1941 .{ }^{26}$ Two other regional opportunities for collegial and educative exchanges were American: the annual Conference of Eastern College Librarians held at Columbia University and the College Section of the Pacific Northwest Library Association that met periodically in Vancouver and Victoria. ${ }^{27}$ Generally, university librarians relied mostly on the activities of the ALA's College and Reference Library Section for professional development and working concerns. This group became an active forum for presentations on professional status, interlibrary 
loans, standards, finances, reference and bibliographic services, support for courses, relationships with faculty and students, and utilization of personnel. When the ALA met in Toronto in 1927, Fred Landon contributed a paper on Canadian history at the section's joint meeting with the Bibliographical Society of America. ${ }^{28}$ Nathan Van Patten, Queen's University, was elected to the section executive for 1927-28. ${ }^{29}$ Later, in 1934, when the ALA convened in Montreal, W. S. Wallace, the chair for 1933-34, led the section's general meeting. By the end of the decade, a new ALA journal, College \& Research Libraries, was offering Canadians opportunities for specialized publication. ${ }^{30}$ Obviously, the range and depth of American influence was powerful in education and workplace initiatives. To be progressive, Canadian academic librarians regularly followed practices and adapted concepts developed in the United States.

\section{Carnegie Programs for College Libraries}

Libraries in Canada spurred thinking on the part of librarians about projects on a broad scale such as a national library, a national association, or public library services for rural Canadians. The library status quo in higher education seemed satisfactory. Although the report's American sponsor was a source of support for proposals for university and college libraries, only one Canadian university, Victoria (Toronto), had benefited (1910) from the earlier Carnegie capital building program. ${ }^{31} \mathrm{~A}$ few libraries - Dalhousie, Memorial, Toronto - had received modest Carnegie grants for specific purposes before 1930 for books or extension work. However, after suspension of the original building scheme and with the arrival of Frederick P. Keppel as the Carnegie Corporation of New York (CCNY) president in 1923, library philanthropy at the corporation underwent fresh scrutiny. Increased emphasis was placed on a systematic Carnegie funding program for libraries, notably a formal \$4,170,000 tenyear educational plan adopted in 1926 to develop library school programs, a model graduate school at the University of Chicago, and associated work with the ALA. ${ }^{32}$ By 1928, Keppel had invited William W. Bishop, the influential chief librarian at the University of Michigan, to chair an Advisory Group on College Libraries with Robert M. Lester, Keppel's assistant, as secretary. ${ }^{33}$ Keppel's own views about higher education were well-known from his work, The Undergraduate and His College. He favoured serious reading to "round out" students' cultural experience and he felt that many libraries were deficient in providing recognized general works.

I have a theory that students would read more if college library administration retained less of the old-fashioned attitude of suspicion toward the student. It is significant that this [the library] is almost the only branch of educational machinery in which fines persist. The fact that the incentive for the purchase of books comes from specialists often means the existence of surprising gaps for the general reader. ${ }^{34}$

Bishop's group devised a coherent Carnegie strategy to support general reading in American liberal arts college libraries based on an evaluation of a library's general 
merit, its potential to be an exemplar, and its undergraduate holdings. ${ }^{35}$ Using a questionnaire sent to institutions (which served as a scorecard for each library), a list of suitable books for college libraries devised by Charles B. Shaw (Swarthmore College), a centralized purchasing scheme with Baker and Taylor Co. (New York book jobbers), and inspections of applicants, the advisory group began recommending book grants for American libraries in March 1930. Award recipients were free to make their own book selections and receive discounted prices through the centralized ordering and processing scheme arranged by the Carnegie advisors. Eventually, by early 1932, the CCNY had authorized book grants totalling $\$ 911,000$ for seventy-eight college libraries, payable over two to five years. ${ }^{36}$ Bishop later judged the American grants to be a "godsend," coming as they did at the height of the Depression "when without them they [recipients] would probably have been obliged to curtail or even cease their purchase of new books." 37

Could the American plan be extended to Canada? For the most part, only sketchy information about library holdings, suitability of buildings, finances, staff competencies, and forward-looking administrators was available to Carnegie officials. The CCNY was somewhat familiar with the situation of university libraries in eastern Canada. The corporation's 1922 study of higher education in the Maritimes, which had called for the centralization of universities at Halifax, made several passing references to libraries in the region. King's College was "not kept up," collections at St. Francis Xavier and New Brunswick were "small," St. Dunstan's appeared to "be used only by the priests," while Acadia's building was superior to Dalhousie's, which had "32,000 volumes and no professional librarian." ${ }^{38}$ Some administrators were wary of rising American influences. Archibald MacMechan, a man of letters and a scholar as well as serving as Dalhousie's librarian from 1906 to 1932, decried the loosening of British ties:

American influence is seen even more plainly in our universities. The curriculum, text-books, methods of teaching, oversight of students, 'credits,' are borrowed from the United States. Organization and administration are on the American model. Among the students, American ideas prevail. ${ }^{39}$

Notwithstanding the reservations of MacMechan and others like him, some Canadian library directors saw the potential in American assistance. They realized that the CCNY was a source of aid for progressive changes. For example, the formation of a graduate library school at McGill after 1927, under Gerhard Lomer, became an important long-term Carnegie educational project supported until 1940. However, the CCNY did not wait for Canadian proposals to further the library's standing in Canadian higher education.

In fact, while the corporation was awarding American college book grants in 1930, Frederick Keppel was considering a similar distribution to Canadian colleges. ${ }^{40}$ Normally, as a first step, the corporation tapped the knowledge of experts to develop programs or to release funds from its British Dominions and Colonies Fund. ${ }^{41}$ At a meeting with Robert Lester in November 1930, William Bishop agreed to be 
a connecting link between the American book program and a separate Canadian advisory committee. ${ }^{42}$ When the two men met again at Ann Arbor in early 1931, they discussed forming an advisory group with representatives from the Maritimes, Montreal, the University of Western Ontario, Toronto, and some college presidents. They both agreed "don't use [John] Riddington [sic]" due to his propensity (in Bishop's opinion) to be "diffuse and long-winded" and because of his testy relationship with George Locke (see Figure 2), who was emerging as their choice as the advisory group's chair. They settled on $\$ 225,000$ as a grant total to fund book awards for "the Canadian job." ${ }^{43}$ By April, Frederick Keppel was writing to Locke with a preliminary plan drafted by Lester. One month later, a Canadian advisory committee composed of Locke, Frederic W. Patterson (see Figure 3), president of Acadia University, Fred Landon (see Figure 4), Bishop, and Lester was struck. The first meeting was scheduled to take place at the Toronto Public Library on June 12, 1931.

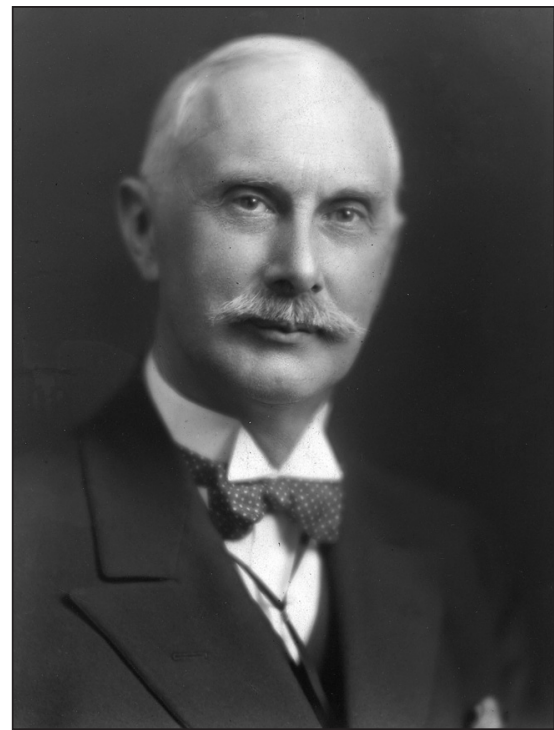

Figure 2. George H. Locke, Toronto Public Library, n.d. Milne Studios, Victoria University Archives, Toronto, no. 11611.

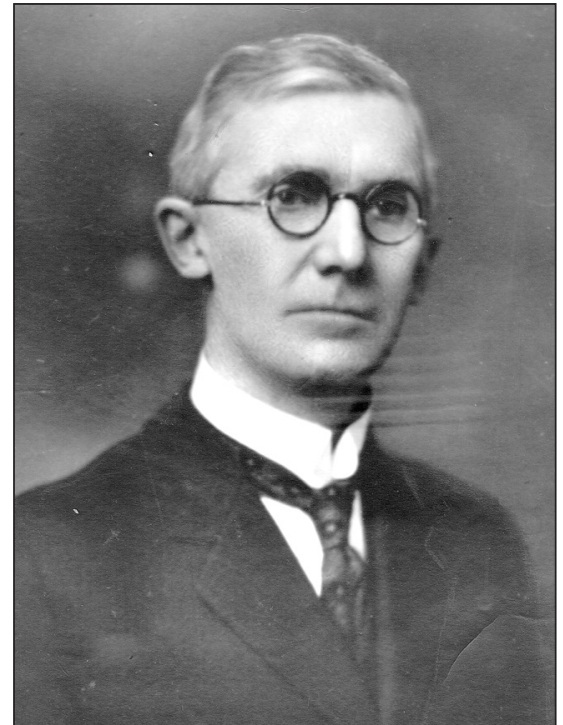

Figure 3. Frederic W. Patterson, Acadia president, c. 1923. Acadia University, Esther Clark Wright Archives, APC394.

\section{The Advisory Group Meetings, 1931-33}

All the members attended the productive preliminary meeting held in Toronto in June. First, Locke was formally elected chair; Lester became recording secretary. The group composed a tentative list of institutions to contact and designated spring 1932 as a provisional target for making book grant recommendations to the CCNY. Members decided to develop an appendix to the Shaw List (used by Bishop's American committee) to better suit Canadian circumstances and preferences. ${ }^{44}$ As well, a revised scorecard, based on a survey instrument mailed to each library, could 


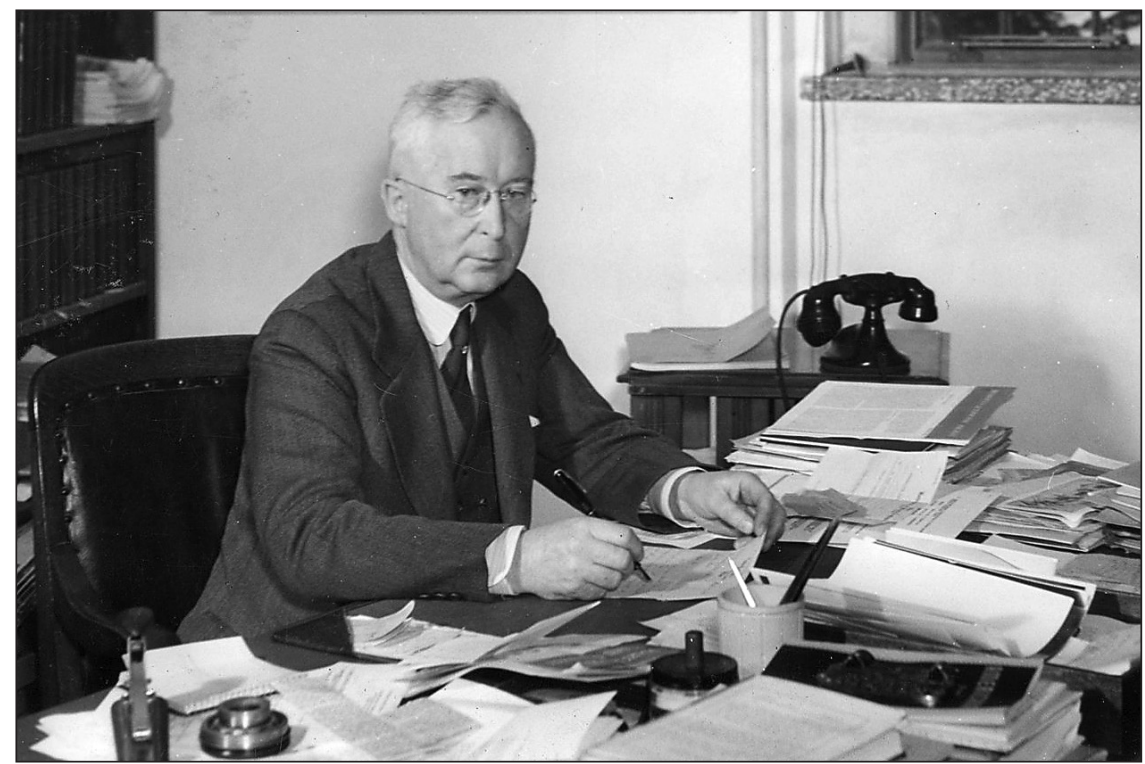

Figure 4. Fred Landon, University of Western Ontario, c. 1939-45. Ivey Family London Room, London Public Library, PG E82.

be helpful. Newfoundland, where substantial Carnegie support was well underway for Memorial College, ${ }^{45}$ would be included for consideration. The group discussed usage of a Quebec consultant and the need for an investigator to report on college library conditions. A fall meeting in Toronto was arranged for November 23. Afterwards, during the summer, the three Canadians began working on the revised list of books that would be used as a checklist for holdings and for selection purposes. Later, at the fall Toronto meeting, Patterson and Landon reported that their contribution to the supplemental appendix was "practically complete." A revised list of forty colleges was drawn up for consideration that included junior colleges with two full years of "acceptable collegiate work." Hugh C. Gourlay, a Canadian graduate from Queen's (BA 1922) who worked for Bishop at Michigan, would do the inspections under Locke's direction. Summer 1932 was set for final recommendations and a news release was prepared emphasizing the group's thrust:

... the Canadian Advisory Group will in its study collect and analyse extensive information as to the financing, administration and holdings of the individual liberal arts College libraries. It is not contemplated that aid of any kind for buildings, salaries, equipment or renovations will be considered, nor will grants be made for research or for special collections. ${ }^{46}$

It fell on Locke's shoulders to coordinate the mailing of a twenty-four-question survey to prospective library administrators (or committee chairs) and to tabulate book suggestions for the creation of a Canadian list. By March 1932, he reported some 
progress: Gourlay could commence his tour in the late spring but the checklist of books was lagging because "the co-operation of professors is a myth." ${ }^{47}$

Hugh Gourlay's inspections took place in the western provinces, Ontario, and Quebec. Excerpts from his June 1932 reports confirmed the undeveloped state of central library facilities, holdings, administration, and staff. He cited few examples of exemplary work. ${ }^{48}$

Alberta: "The library has excellent, though crowded, accommodations..."

Mount Royal: "The registrar is the nominal librarian with a full time student in charge of the library."

Regina: "The library, however, has been used for recitals, teas, meetings of all kinds, freshmen singsongs, etc.... The president has felt the need of a librarian, or at least a full time person in charge, but funds have not been available." ${ }^{49}$

Saskatchewan: "[books are] housed in a series of rooms in the main library - lack of space, over-crowding, bad cataloging make the collection of 47,000 books difficult to use."

Manitoba: "The president does not understand the library and hampers its efficiency by too rigid attention to minor details."

Brandon: "The college spends $\$ 458.00$ per year on its library."

Assumption: "The book collection is fair but needs strengthening all around - much dead wood on the shelves including medical books which are of no use to the college."

Waterloo: "President is interested in developing the library, but doesn't know where to start."

Ottawa: "Cataloging is extremely primitive. Rector plans sending librarian to library school-librarian is active and progressive but hampered by lack of knowledge."

Toronto: "The librarian feels that the undergraduate needs at present are being taken care of."

Bishop's: "The assistant librarian, a lady of advanced years, knows nothing about the library, and spends the morning hours when on duty, in knitting."

McGill: "It [Redpath Library] is badly over-crowded but tentative plans have been made to secure additional reading room space in the adjacent Presbyterian college."

Montreal: "There is no library for the university..."

Laval: "The 'general' library is mainly used for reference. There is very little seating accommodation and the use [of reference books] is somewhat restricted."

To facilitate travel schedules, the group (including Gourlay but without Bishop) convened at Pictou Lodge, Nova Scotia on June 28-29, 1932 in order to begin making 
book grant recommendations. Patterson, Acadia's president since 1923, knew the conditions of most Atlantic colleges and universities. Locke and Landon were familiar with southern Ontario libraries and, to some extent, those in Quebec.

During the course of the first day, June 28, at the Canadian National Railway seaside resort, committee members weighed the undergraduate reading needs of fortyone libraries, but also gave careful consideration to geography, denomination, and specific local factors. There is no evidence that responses from the mailed questionnaires were considered during the discussions. ${ }^{50}$ The members systematically voted to recommend sixteen book grants ranging from $\$ 1,500$ to $\$ 15,000$ on an unconditional basis: $\$ 131,100$ in total for those able to administer them effectively and use them to good advantage. Afterwards, a decision was reached about another ten institutions on a conditional basis, for a total of $\$ 50,400$, the grants ranging from $\$ 2,400$ to $\$ 9,000$ (see Table 2). The group voted to defer action, pending further study on existing organization and administration, on eight institutions, including Manitoba and McGill. No recommendations were made by the committee on seven additional libraries that had not demonstrated evidence of organization and resources sufficient to justify a grant. The members spent the second day preparing a statement of general terms governing the grants and specifications for conditional improvements. Five points emerged: (1) grants were for books and current periodicals for general undergraduate reading, together with Library of Congress cards for purchases and the updated Shaw List available for checking holdings; (2) grants would be payable in three annual instalments; (3) grants were to supplement, not replace, normal annual expenditures for resources; (4) the advisory group could continue to recommend changes during the payment period; and (5) colleges were to keep separate lists of purchases and report progress, usually in July. Lastly, before adjourning, the advisory group members approved a further sum of $\$ 35,000$ to be held in abeyance for the unresolved places. ${ }^{51}$ Adding $\$ 5,000$ for administrative expenses, they had allotted $\$ 221,500$ for the entire project.

Table 2

Grants to Universities and Colleges, 1932-1935

\begin{tabular}{|l|c|c|l|}
\hline University & Grant & \multicolumn{1}{|c|}{ Payments } & Conditions/Date \\
\hline Memorial & $\$ 3,000$ & $\$ 1,000$ annually for 3 yrs & unconditional, 1932 \\
\hline $\begin{array}{l}\text { Prince of } \\
\text { Wales College }\end{array}$ & $\$ 4,500$ & $\$ 1,500$ annually for 3 yrs & $\begin{array}{l}\text { replace collection destroyed } \\
\text { by fire; implement proper } \\
\text { classification and cataloguing, } \\
1933\end{array}$ \\
\hline St. Dunstan's & $\$ 1,800$ & $\$ 600$ annually for 3 yrs & continue librarian's work, 1933 \\
\hline Acadia & $\$ 15,000$ & $\$ 5,000$ annually for 3 yrs & unconditional, 1932 \\
\hline Dalhousie & $\$ 9,000$ & $\$ 3,000$ annually for 3 yrs & $\begin{array}{l}\text { secure trained assistant; } \\
\text { rearrange reading room; provide } \\
\text { systematic cataloguing, 1932 }\end{array}$ \\
\hline
\end{tabular}




\begin{tabular}{|c|c|c|c|}
\hline University & Grant & Payments & Conditions/Date \\
\hline King's College & $\$ 3,000$ & $\$ 1,000$ annually for 3 yrs & $\begin{array}{l}\text { implement open shelves in } \\
\text { reading room; add a trained } \\
\text { assistant, } 1932\end{array}$ \\
\hline $\begin{array}{l}\text { St. Francis } \\
\text { Xavier }\end{array}$ & $\$ 4,500$ & $\$ 1,500$ annually for 3 yrs & $\begin{array}{l}\text { add one trained person; rearrange } \\
\text { holdings, } 1932\end{array}$ \\
\hline Mount Allison & $\$ 4,500$ & $\$ 1,500$ annually for 3 yrs & $\begin{array}{l}\text { add trained librarian and assistant, } \\
1932\end{array}$ \\
\hline $\begin{array}{l}\text { New } \\
\text { Brunswick }\end{array}$ & $\$ 4,500$ & $\$ 2,250$ annually for 2 yrs, & add trained person, 1932 \\
\hline $\begin{array}{l}\text { St. Joseph's } \\
\text { College }\end{array}$ & $\$ 1,000$ & payable 1934-35 & unconditional, 1933 \\
\hline Bishop's & $\$ 4,500$ & $\$ 1,500$ annually for 3 yrs & $\begin{array}{l}\text { reconstruction of library and } \\
\text { trained assistant for cataloguing } \\
\text { and classification, } 1933\end{array}$ \\
\hline McGill & $\$ 15,000$ & $\$ 5,000$ annually for 3 yrs & $\begin{array}{l}\text { expand undergraduate facilities } \\
\text { managed by trained assistant, } \\
1933\end{array}$ \\
\hline $\begin{array}{l}\text { Montreal } \\
\text { School } \\
\text { of Higher } \\
\text { Commercial } \\
\text { Studies }\end{array}$ & $\$ 3,000$ & $\$ 1,000$ annually for 3 yrs & $\begin{array}{l}\text { grant for general undergraduate } \\
\text { studies, } 1933\end{array}$ \\
\hline Laval & $\$ 6,000$ & $\$ 2,000$ annually for 3 yrs & unconditional, 1932 \\
\hline $\begin{array}{l}\text { Stanstead } \\
\text { College }\end{array}$ & $\$ 1,800$ & payable 1932-33 & unconditional, 1932 \\
\hline Ottawa & $\$ 4,500$ & $\$ 1,500$ annually for 3 yrs & $\begin{array}{l}\text { enlarge facilities; provide trained } \\
\text { assistant for cataloguing, } 1932\end{array}$ \\
\hline Queen's & $\$ 15,000$ & $\$ 5,000$ annually for 3 yrs & unconditional, 1932 \\
\hline McMaster & $\$ 6,000$ & $\$ 2,000$ annually for 3 yrs & unconditional, 1932 \\
\hline Toronto & $\$ 15,000$ & $\$ 5,000$ annually for 3 yrs & $\begin{array}{l}\text { unconditional for University } \\
\text { College Library, } 1932\end{array}$ \\
\hline Trinity College & $\$ 6,000$ & $\$ 2,000$ annually for 3 yrs & $\begin{array}{l}\text { add full-time trained librarian; } \\
\text { implement modern classification } \\
\text { and cataloguing, } 1932\end{array}$ \\
\hline $\begin{array}{l}\text { Victoria } \\
\text { University, } \\
\text { Toronto }\end{array}$ & $\$ 15,000$ & $\$ 5,000$ annually for 3 yrs & unconditional, 1932 \\
\hline $\begin{array}{l}\text { Western } \\
\text { Ontario }\end{array}$ & $\$ 15,000$ & $\$ 5,000$ annually for 3 yrs & unconditional, 1932 \\
\hline $\begin{array}{l}\text { Waterloo } \\
\text { College }\end{array}$ & $\$ 2,400$ & $\$ 800$ annually for 3 yrs & $\begin{array}{l}\text { add trained cataloguer; rearrange } \\
\text { rooms; provide supervision, } 1932\end{array}$ \\
\hline $\begin{array}{l}\text { Ursuline } \\
\text { College } \\
\text { [Brescia] }\end{array}$ & $\$ 1,500$ & $\$ 500$ annually for 3 yrs & unconditional, 1932 \\
\hline Alma College & $\$ 500$ & payable 1933-34 & unconditional, 1933 \\
\hline
\end{tabular}




\begin{tabular}{|l|c|c|l|}
\hline University & Grant & \multicolumn{1}{|c|}{ Payments } & Conditions/Date \\
\hline $\begin{array}{l}\text { Assumption } \\
\text { College }\end{array}$ & $\$ 2,400$ & $\$ 800$ annually for 3 yrs & unconditional, 1932 \\
\hline Saskatchewan & $\$ 9,000$ & $\$ 3,000$ annually for 3 yrs & $\begin{array}{l}\text { secure full-time librarian; adopt } \\
\text { standard system of classification } \\
\text { and cataloguing, 1932 }\end{array}$ \\
\hline Luther College & $\$ 2,400$ & $\$ 800$ annually for 3 yrs & unconditional, 1932 \\
\hline $\begin{array}{l}\text { Campion } \\
\text { College }\end{array}$ & $\$ 1,500$ & $\$ 500$ annually for 3 yrs & unconditional, 1932 \\
\hline $\begin{array}{l}\text { Regina } \\
\text { College }\end{array}$ & $\$ 3,000$ & $\$ 1,000$ annually for 3 yrs & $\begin{array}{l}\text { organize library responsibility; } \\
\text { provide exclusive use for library } \\
\text { purposes, 1932 }\end{array}$ \\
\hline $\begin{array}{l}\text { Alberta } \\
\text { Mount Royal } \\
\text { College }\end{array}$ & $\$ 15,000$ & $\$ 5,000$ annually for 3 yrs & unconditional, 1932 \\
\hline $\begin{array}{l}\text { British } \\
\text { Columbia }\end{array}$ & $\$ 15,000$ & $\$ 5,000$ annually for 3 yrs & unconditional, 1932 \\
\hline $\begin{array}{l}\text { Victoria } \\
\text { College }\end{array}$ & $\$ 3,000$ & $\$ 1,000$ annually for 3 yrs & unconditional, 1933 \\
\hline
\end{tabular}

Source: Information compiled from Advisory Group on Canadian College Libraries files.

Work continued through summer 1932, especially on compiling the Canadian appendix to Shaw's bibliography and on gathering information about outstanding libraries. When Bishop, who had been unable to attend the June meeting, returned to Michigan in July, he raised some concerns. Because McGill had not been recommended for a grant, he wrote to Lester to say he was disturbed and that he hoped the rivalry between Toronto and McGill and Locke and Lomer would not cloud the program's general effect. Lester replied that it first seemed McGill "did not want a grant" but that further contacts with the principal and vice-chancellor, Sir Arthur Currie, would likely result in a grant being awarded at the next meeting. ${ }^{52}$ In the same week, Lester received a letter from Locke declaring that he had decided to scrap the Canadian supplement to the Shaw List but hoped eventually to produce a worthwhile "listing" by the autumn. ${ }^{53}$ Lester soldiered on by gathering recommendations on libraries from the advisory group members in order to allow Frederick Keppel to present the Carnegie trustees in early October with a statement of recommended Canadian grants for authorization. A major impediment was a scandal at Manitoba, where John A. Machray, chair of the Board of Governors, pleaded guilty to the theft of university endowment funds and was sentenced to seven years' imprisonment. ${ }^{54}$ When the Carnegie trustees met in New York on October 11, they approved twentyeight Canadian grants totalling $\$ 187,800$. Prince of Wales College $(\$ 4,500)$ and St. Dunstan's $(\$ 1,800)$ in Charlottetown, Prince Edward Island, had been added to the list of recipients after the Pictou Lodge deliberations. President Keppel, who visited Prince of Wales in person in summer 1932, had asked McGill's library director, Gerhard Lomer, to survey the entire island's prospects for a short-term regional 
demonstration to coordinate public library service. Lomer confirmed the needy condition of both college libraries in the autumn. ${ }^{55}$ Shortly afterwards, Lester wrote to Locke suggesting a fall meeting specially to get additional recommendations in shape for final CCNY action. ${ }^{56}$ Lester, Bishop, and Landon were concerned with McGill's status and Patterson had raised a case for Brandon College as well. ${ }^{57}$

All the members of the advisory group, Gourlay included, convened at the Toronto Public Library on November 21, 1932. Lester reported that all the recipients had been notified and that the first instalments of unconditional grants would be issued after December 1. Once conditions satisfied the chair, instalments for other recipients could be paid. After discussion, the committee formally voted that Prince of Wales, New Brunswick, Ottawa, Saskatchewan, and Trinity College had not made acceptable progress. Locke was instructed by his colleagues to continue to offer guidance as necessary. The group deferred action on Manitoba and its affiliates - Wesley, St. Boniface, St. John's, and St. Paul's - but requested that the CCNY retain these colleges on its list for review at some later date. Victoria (BC), Brandon, Mount St. Vincent, and Bishop's were added to the list for further consideration. Two outstanding issues were then resolved. Members reported that McGill was making readjustments to provide space for undergraduates, and therefore a $\$ 15,000$ grant was voted. This action was "a very acceptable olive branch," according to Frederick Keppel. ${ }^{58}$ The University of Montreal, which did not have a main library due to the closure of Saint-Sulpice in summer 1931, was voted $\$ 3,000$ for its affiliate, École des hautes études commerciales de Montréal. Lastly, the five members agreed to continue to liaise during the three-year period of advisement for conditional grant recipients.

News about the awards spread quickly. Undergraduates and graduate students, who paid library fees, had a vested interest in library improvement. Their newspapers expressed satisfaction about receiving grants and described awards as a progressive measure that would improve conditions. The new president of Dalhousie, Carleton Stanley, immediately acknowledged a $\$ 9,000$ grant at the same time that the Macdonald Memorial Library (opened in 1916) was being better organized. The seating division between men and women was removed, reference books were placed on open shelves, reserve books were kept at the circulation desk, and increased hours on Saturday morning and Sunday afternoon were added. ${ }^{59}$ The Varsity reported that the East Hall in University College would now be devoted to undergraduate reading (mainly duplicates) in order to free up space in Toronto's main library basement as early as November. ${ }^{60}$ An editorial in Queen's journal applauded the nomination of three student representatives to the book selection committee and stressed the need to act responsibly: "Should the undergraduate body of Queen's fail to take advantage of the generous gift the University will suffer a distinct loss and the students will deprive themselves of invaluable reading material." ${ }^{\prime 1}$ The Ubyssey reported that the scheme would elevate UBC's main library's (see Figure 5) standards and curtail service declines. ${ }^{62}$ National newspapers in Canada's two largest cities also picked up on the grants, but focused on local issues. When McGill's grant was announced by Sir Arthur Currie, information included that the Redpath Library already had 8,668 (63 


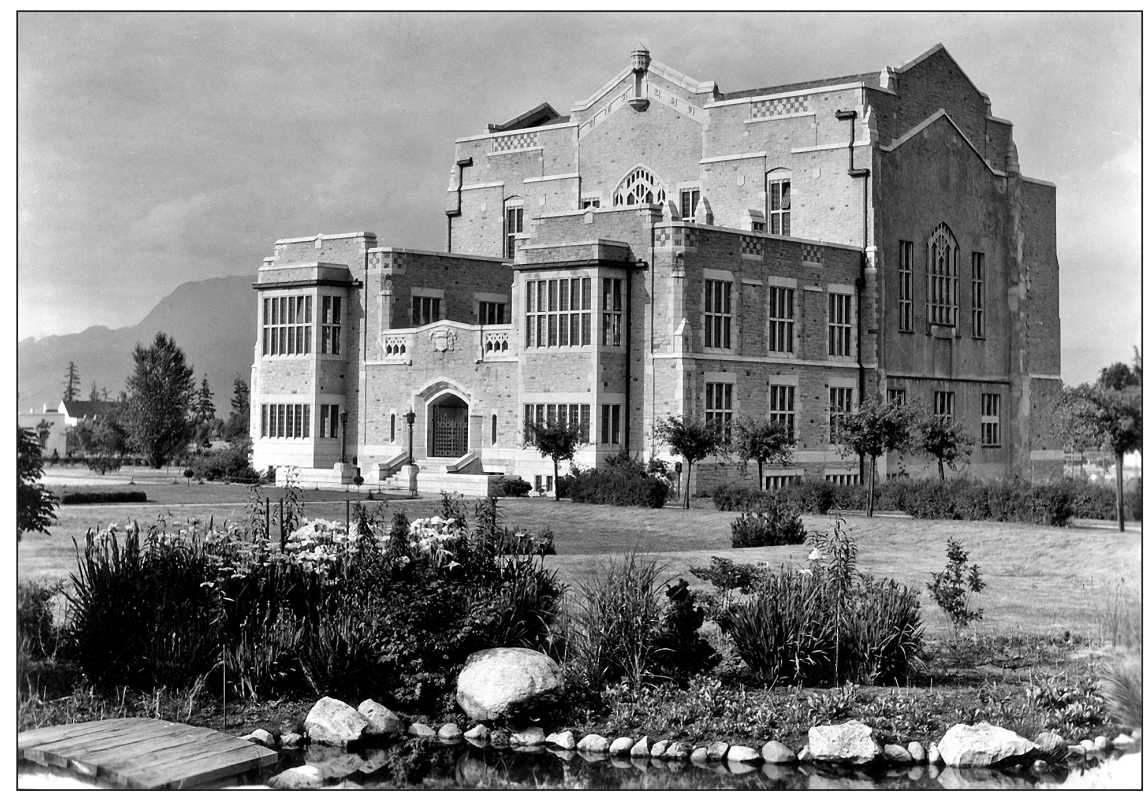

Figure 5. University of British Columbia, Main Library, 1932. Photographer, Philip Timms. UBC Archives, 1.1/1727.

per cent) of the 13,798 titles in the Shaw List. ${ }^{63}$ The Globe skipped over the rationale for undergraduate reading entirely by highlighting Toronto’s $\$ 15,000$ grant as a way to free up space for advanced students and professors in the main library. ${ }^{64}$

The committee members carried on their work into 1933, especially Locke, who was actively involved in resolving issues associated with conditional grants. In February 1933, three more colleges received word they would be sharing in the program: Victoria College $(\$ 3,000)$, Bishop's $(\$ 4,500)$, and Trinity $(\$ 6,000)$. Victoria College had progressed following its affiliation with UBC in 1920, housing 3,000 catalogued books in a room inside its new campus home, Craigdarroch Castle to support initial undergraduate work. Trinity had agreed to hire a trained librarian. One sensitive item, the Canadian list, remained elusive. When Bishop requested a listing for Michigan to use, Locke brazenly responded, "I think we might have had a small list, but there was no demand for it, and nobody who had time to take it on." ${ }^{5}$ This response put the matter to rest - there would be no Canadian appendix to the Shaw List. Because Canadian grants were made directly to the universities and colleges concerned, and no efforts were made to centralize book purchases, Locke possibly believed it was more productive to follow up on local conditions related to improvements in management, cataloguing, and finances rather than consuming his time with the book supplement. ${ }^{66}$ After Bishop wrote to Lester about Locke's increasingly arbitrary course, Lester replied he would try to get Locke "on the right track" at an opportune time.${ }^{67}$ Bishop agreed, noting that Locke could be temperamental and had not been very well for a few years. ${ }^{68}$ 
As chair of the advisory group, Locke felt it his duty to immerse himself in many details about the conditions of grants at each institution. Lester bided his time and by the end of April Locke was able to report more progress on conditional awards. ${ }^{69}$ Dalhousie and King's College had arranged co-operative purchasing and employed a catalogue librarian, thus avoiding unnecessary duplication and affording timely access. Walter Murray, president of the University of Saskatchewan, had also reluctantly agreed to appoint a promising librarian, Marjorie Sherlock, as catalogue assistant. However, New Brunswick's president, Cecil C. Jones, continued to hold out on the issue of hiring a trained librarian. Unfortunately, Locke temporarily became sidetracked by an article in the British Library Association Record, sourced from a "leading American librarian" (Bishop), on the Canadian group, which he felt misrepresented Canadian college conditions and, worse still, suggested that McGill had the best university library in the country. He complained to Lester, who answered diplomatically it "is not from my hand" and urged resolution of outstanding grants and a summer date for a wrap-up meeting. ${ }^{70}$ In May, both Landon and Locke went to Winnipeg to check Manitoba's small collections housed in buildings on the Fort Garry and Broadway campuses. They knew the head librarian, Frank E. Nuttall, had little influence in library matters. ${ }^{71}$ In August, Frederick Keppel and Lester met to assess the group's future. They decided to defer action on Manitoba altogether and wind up Canadian activities before the end of the year. ${ }^{72}$

The advisory group members (less Bishop and Gourlay) gathered for the last time at Boston Public Library on the afternoon of October 20, 1933. ${ }^{73}$ Locke and Landon reported a successful conclusion at UNB. After Landon had put the point concisely in an earlier letter stating, "what the library of New Brunswick needs is the appointment of a trained librarian to its staff," President Jones finally hired an assistant primarily for cataloguing the library's purchases. ${ }^{74}$ Consequently, the conditions for UNB to receive a grant were fulfilled and the committee assented to $\$ 4,500$ over two years. Then the group approved a small grant — \$500 payable in 1933-34 — for Western's affiliate, Alma College. ${ }^{75}$ Lester was able to report that the CCNY had made special grants in the Maritimes and western provinces as follows: Dalhousie, \$125,000; Mount Allison, \$125,000; Prince of Wales, \$75,000; Alberta, \$50,000; British Columbia, \$50,000; Manitoba, \$50,000; and Saskatchewan, \$50,000. The latter two awards went towards developing "junior divisions" for the early stages of undergraduate work related to libraries. ${ }^{76}$ Locke presented a report on accomplishments, book selection, and problems encountered. He judged that the "whole college world in Canada has been stirred by this grant to libraries more than by any other thing that has ever happened."77 At the end of the afternoon, Lester thanked the members and they adjourned indefinitely.

\section{Effects and Results of the Carnegie Book Grants}

By the end of 1933, the major work of the advisory group was essentially complete. Recipients would continue to file reports of progress each year as the schedule of payments unfolded. Locke continued to monitor the annual grants by corresponding 
with colleges and sending reports to Lester, for example, noting at the end of 1934 that he had objected strongly to selection practices at Prince of Wales and Mount Royal. ${ }^{78}$ In general, the CCNY program aimed to improve local services provided to undergraduates; to awaken university administrators to the potential of a good library; and to promote the library more as a service-oriented partner with faculty and less as a repository of books. Locke's final report at Boston summarized four emerging trends supported by the Carnegie program. First, libraries were now furnishing books required for collateral reading in connection with the courses and materials faculty designated for their own instructional needs. Second, the library was supplying books for voluntary student reading and encouraging their use. Third, librarians were providing wide-ranging book selection covering all fields of knowledge and making the content easily accessible through proper cataloguing and classification. Finally, librarians were training students in the use of library resources, thereby better integrating holdings with academic programs. Supporting evidence for Locke's ideas appears in a variety of contemporary Canadian sources. Because the CCNY did not formally investigate the results of its book grants in the United States or Canada, the direct and indirect effects of the college book programs cannot be determined with certainty. ${ }^{79}$ Success could not be proven by the quality or quantity of books, nor could it be denied. Frederick Keppel preferred to lead by example and enable local administrators. The CCNY's informed experts supervised funded projects and submitted progress reports in stages. Keppel's works in Canada, like those in Australia and New Zealand, ventured into new areas of research and alternative library organizational and service patterns. ${ }^{80}$ The reports of knowledgeable advisors were sufficient grounds for Keppel and Lester to take action. The achievement of these pioneering efforts depended on the interplay between the network of experts and the beliefs, attitudes, and pragmatism of men and women and the circumstances of the institutions they represented. ${ }^{81}$ In the case of George Locke, the scope of individual action was increased, because his ability to influence university presidents or college administrators stemmed from the structure of the Carnegie program he chaired.

The success of the Canadian Carnegie program must be measured within the context of the hard times brought on by the Great Depression when budget cuts, reductions in wages, layoffs, suspended priorities, and lower expectations were shared features across the Dominion. In a time of economic depression and flat enrolment, recipients were grateful for a funding opportunity and adapted their co-operative responses, taking into account their particular circumstances. Donald Cameron offered a standard opinion in his annual report for 1932-33: Alberta's new Carnegie purchases stimulated the library and were of utmost value. ${ }^{82}$ John Ridington's admission that, "but for this grant, the library would have received no additions to its book collection, except such as came by way of personal or institutional gift" rang true. ${ }^{83}$ Mary Ingraham's 1934 and 1935 reports summarized Acadia's library experience. Even though President Patterson was forced to cut Acadia's library salaries by 10 to 15 per cent, ${ }^{84}$ she managed to purchase many new books and began the change from the Dewey Decimal classification system to the Library of Congress (LC) system: "The advantages of the newer system are obvious, especially in respect to the 
printed cards." ${ }^{85}$ George Locke had noted the value of cataloguing in his dealings with institutions. The value of LC classification and the potential use of printed cards in Canada can be counted as one stimulus effect of the Carnegie program. Most academic libraries did not use LC; McGill and Alberta, for example, used the Cutter system, with modifications, and smaller colleges preferred the Dewey system. ${ }^{86}$ The grant awards could be used to order LC card sets, something Mary Ingraham noted, and, helpfully, the Shaw List provided LC card numbers for this purpose. A decade earlier, Queen's University had already demonstrated the potential of co-operative cataloguing and the use of LC cards, although W. S. Wallace had sounded a skeptical note about its potential costs. ${ }^{87}$ Another practical achievement of Carnegie acquisitions was the recognition that cataloguing and classification required training and expertise. Locke was insistent on this point: "I had not known that anybody had suggested that a High School graduate with a little technical training was competent to catalogue college books. Certainly no one on our Committee would countenance such a statement." ${ }^{8}$ The conditions imposed for most libraries included securing trained staff to ensure proper cataloguing and classification for both current holdings and Carnegie grant purchases (Table 2).

Undoubtedly, a positive result of the advisory group's grant conditions was the employment of academically-qualified librarians, often young women, as assistants or cataloguers who were capable of advancing through the ranks. They were representative of a growing movement of professionally educated and trained women aspiring to academic work. An Alberta native, Marjorie Sherlock held a BA and MA from Oxford before starting at Saskatchewan, moving to Queen's in 1941, and serving as Alberta's university librarian from 1945 to $1955 .{ }^{89}$ Margaret Ray (BA, Victoria, Toronto) wrote about the potential for women in the professions shortly before she assumed management duties at Victoria's Carnegie reading room; she later served as chief librarian from 1952 to $1963 .{ }^{90}$ Winifred H. Snider (BA, Victoria, Toronto), hired at Waterloo College to catalogue Carnegie purchases, moved to Sackville, NS, and was Mount Allison's head librarian from 1942 to $1945 .{ }^{91}$ As well, Hugh Gourlay benefited from the program in which he participated. After receiving his MALS at Michigan, he returned in 1935 as McMaster's chief librarian, making an immediate contribution to the nation's embryonic library literature. ${ }^{92}$

Library book selection for courses and interrelated subjects and provision for student recreational reading, two trends Locke suggested the Carnegie program strengthened, varied across the country. If use of the Shaw List engendered some resistance to a program that might steer Canadian decisions towards American preferences, it was not raised publicly. Americans, too, were cautious about central direction: a select panel analyzing all the CCNY library programs determined that "care should be taken to maintain freedom of selection on the part of the college and to stimulate the library staff to exercise such choice wisely." 93 Shaw's Books for College Libraries proved to be a useful selection tool for larger libraries. ${ }^{94}$ John Ridington immediately set to work checking UBC's holdings and discovered that 6,192 out of 14,106 titles were held, almost 44 per cent. He followed with a request to other libraries as to whether they intended to use Shaw's work to correct disparities in subject areas not 
taught or to select in terms of teaching priorities. ${ }^{95}$ At Victoria University, Toronto, local arrangements, mostly course-related reading, predominated in acquisitions. The librarian, Dr. F. Louis Barber, quickly organized a Carnegie Purchase Committee that divided the grant by subjects for faculty and committee members as follows:

- $\$ 1,200$ for general, librarian to select

- \$500 each for English, Economics, Science

- $\$ 400$ each for Classics, History

- $\$ 300$ each for French, German, Philosophy

- $\$ 100$ each for Sociology, Psychology, Oriental, Religion, Mathematics. ${ }^{96}$

When the committee met again, it modified the appropriations to account for the first two grants. By the end of 1934, Victoria's circulation in one reading room had doubled and increased by two-thirds in another. Barber also reported receiving frequent book suggestions from students. ${ }^{97}$ Memorial's library committee proposed to spend its grant on books and a few periodicals for four subjects: American and Empire literature, education, and French. The immediate effect of the new Carnegie books was "all to the good" and had met with general approval a year later. ${ }^{98}$

Local circumstances usually shaped student responses to book purchases. At Queen's, a book selection committee augmented with students reportedly worked according to the principle that it should cater to all tastes and that a "man's reach should exceed his grasp." Accordingly, less conventional topics - crime, fiction. folklore, sports and games, travel and war, and aviation - began to rest on Douglas Library shelves. ${ }^{99}$ Complaints about the absence of bestsellers, such as Gone with the Wind and Eyeless in Gaza, were balanced by the university librarian's rejoinder that fiction of "permanent literary value" would be considered. ${ }^{100}$ In this instance, the undergraduate collection began to reflect (with some prodding) the variety of novels, interests, and activities that students favoured. However, Queen's students, solidly middle-class like their peers in other universities, felt an obligation to respect educational norms in the liberal-conservative temperament that prevailed on campuses. Campus newspaper editorials urged them to live up to the grant conditions by making good use of new books while at the same time observing lending restrictions on books such as Theodore Van de Velde's Ideal Marriage (1928). ${ }^{101}$ At this time, objectionable books, such as Morley Callaghan's fiction, were normally kept separate from general circulation titles, but could be requested by students if they had good reason. ${ }^{102}$ Opinions about library usage often differed. A college yearbook editor at the relatively small Alma College in southwestern Ontario expressed a positive sentiment:

This has been a banner year for the library. The Carnegie Grant has made it possible for us to round out our reading supply by adding many new books. The library is becoming a popular place and interest in reading is increasing greatly. ${ }^{103}$ 
However, at McGill, despite a new reading area (the "Carnegie Library") in the Arts Building, a very large proportion of junior and senior undergraduates were said not to be taking full advantage because it was combined with the congested freshman reading room. Ergo, a properly planned summer reading program was proposed as a possible remedy for students who had fallen behind in their reading. ${ }^{104}$

George Locke's observation about the impact of book grants on the encouragement of trained staff and their role in integrating the library with courses and providing instruction on library usage is a difficult claim to evaluate. The Carnegie program accentuated the value of acquiring and using undergraduate reference "tools," like the Shaw List, to identify and purchase resources for undergraduate instruction and term papers. ${ }^{105}$ In the 1930 s, there were two emergent models of staff engagement with faculty courses, based on American experience: brief orientation sessions conducted by faculty or library staff, usually on an optional basis, and formal instruction of students in the use of reference books, catalogues, and bibliographies on an elective or required basis. There were very few Canadian advocates for either scheme. ${ }^{106}$ Acadia and Western were leaders in introducing library instruction into the curriculum for degree credit. Mary Ingraham taught Acadia's BA credit courses on library methods, administration, and history from 1918 until 1944. A required library course for first-year students began at Western in the 1920s, but was expanded after a 1930 survey of 200 incoming undergraduates revealed their lack of library knowledge. ${ }^{107}$ Two of Fred Landon's librarian-instructors authored the first Canadian text on library science in 1936; their text was used in courses at Western until the early 1960s. ${ }^{108}$ Students at Acadia and Western could use these courses as a springboard to graduate education at accredited library schools. In Canada, the development of library instruction (student education) and training for prospective librarians (professional education) gained some impetus after McGill inaugurated its graduate program in 1930, leading to a one-year Bachelor of Library Science. Of course, academic libraries could provide more casual library instruction on a limited individual basis in the library as well. E. C. Kyte installed an inquiry desk in the Douglas Library in 1934 to assist students looking for information for essays. ${ }^{109}$ Toronto had established a reference desk in 1925 under Hester Young. She maintained this work until her death in 1938 and apparently developed a standard response to questions by pointing across the hallway saying, "There's the catalogue."110 In the 1930s, the development of Canadian library user education and course-related assistance in higher education was at an experimental stage in response to changing curriculum, available personnel (typically female graduates), and its role in relation to academic courses. ${ }^{111}$

After the Carnegie stimulus came to an end in 1935, Depression economic conditions resumed, emphasizing the value of the acquisitions that had been made during the brief period of grant distribution. Memorial's librarian, Sadie Organ, reported in 1936-37 that "no money for books has been granted and we have had to get along as best we could with chance gifts." 112 The undergraduate reading area at McGill was still crowded, now overrun by "frosh," who monopolized the seats. ${ }^{113} \mathrm{~W}$. S. Wallace's qualms about Sunday openings, that The Varsity continued to raise, lingered, although 
he now considered extending hours in the evenings. ${ }^{114}$ Formal library instruction courses remained an elusive goal for many administrators, such as John Ridington, who reissued his previous 1928 call to institute formal courses for user education in his 1937 Senate report. ${ }^{115}$ The proposed new main library buildings for Toronto and Alberta remained paper scenarios. Fred Landon was the exception to Depression-era constraints. Western was fortunate to receive private funding to erect its new Lawson Library in 1934. ${ }^{116}$ Upon reflection, perhaps the lasting effect of the Carnegie book program was not on the value of grants or the stimulus to undergraduate reading, but on consciousness. General awareness of the value of the library to the academy and the constant need to improve the quality of its holdings and service was gaining gradual acceptance. St. Francis Xavier's 1934 yearbook best expressed the library's elevated status on campus:

Until recent years, it was an insignificant factor in the academic work of the institution. Now, the students are learning how to make an intelligent use of its resources by referring to the card catalogues, bibliographies, magazine indexes, etc. The supervised reading rooms are rarely vacant. The circulation of the present term has more than trebled that of ten years ago and the reference works are constantly in demand. ${ }^{117}$

Clearly, St. Francis Xavier's $\$ 4,500$ Carnegie book grant had helped contribute to the library's improved condition.

The advisory group's work drew attention to the state of academic libraries - the satisfactory and the unsatisfactory — on a national basis at a time when overarching direction or co-ordination did not exist. ${ }^{118}$ No Canadian library organization existed to organize projects, and presidents and administrators meeting at the National Conference of Canadian Universities seldom discussed library issues. Although individual awards were small, the cumulative effect was unprecedented, the equivalent of about \$4,000,000 in 2016 dollars. Library improvements may have been temporary, annual payments small, and the cessation of awards painful in some cases, but Carnegie grants were the axis upon which national college and university library development turned for a short time, gaining a purposeful, opportune impetus for future educative directions after 1935. The Carnegie emphasis on undergraduate reading served as an example for stimulating other ideas about academic library roles, such as assistance to adult education and university extension work, forming comprehensive collections for graduate research, and responding to increased enrolments with better student instruction. ${ }^{119}$ The advisory group's work was an important episode of interwar library progress that illuminates college and university libraries beyond the dreary and routine descriptions that Libraries in Canada and annual statistical compilations convey. Contemporary acknowledgement of the library's potential to influence student's lives in higher education through reading was a progressive step as well as an enhancement to the already distinguished Carnegie library tradition across Canada. 


\section{Notes}

I am grateful to the anonymous reviewers for their helpful recommendations and insights.

1 John Ridington, Mary J. L. Black, and George H. Locke, Libraries in Canada; A Study of Library Conditions and Needs (Toronto: Ryerson Press, 1933), 124-25. This enquiry was conducted shortly before the advisory group was formed.

2 For the impact of continental philanthropy, see William J. Buxton and Charles R. Acland, American Philanthropy and Canadian Libraries: The Politics of Knowledge and Information (Montreal: McGill University, 1998) and Jeffrey D. Brison, Rockefeller, Carnegie, and Canada: American Philanthropy and the Arts and Letters in Canada (Montreal and Kingston: McGill-Queen's University Press, 2005). Both monographs briefly mention the advisory group in broader historical contexts.

3 For example, Geoffrey Briggs, "The Development of University Libraries in Canada," in University Library History: An International Review, ed. James Thompson (New York: Clive Bingley, 1980), 269-86.

4 Paul-Émile Filion, "University Libraries Before and After Williams," in Librarianship in Canada, 1946-1967: Essays in Honour of Elizabeth Homer Morton, ed. Bruce Braden Peel (Victoria: Canadian Library Association, 1968), 73-86; and Bruce Peel, "Canadian University Libraries," in Canadian Libraries in their Changing Environment, ed. Loraine Spencer Garry and Carl Garry (Downsview, ON: York University, 1977), 182-200.

5 "May Open Library Sundays if Needed," The Varsity, February 4, 1930, 1. Wallace simply reiterated his previous position: "Students Don't Use New Privileges," The Varsity, October 19, 1928, 1 and 4.

6 Editorial, "Library Pests," McGill Daily, December 16, 1931, 2.

7 "Corozone Placed in Library," The Gateway, October 30, 1930, 1, and "Faculty Makes Daring Admission," The Gateway, February 13, 1931, 1.

8 "Wanted-A Library," College Times, December 1929, 1.

9 W. S. Wallace, "The University Library of To-day - and To-morrow," University of Toronto Monthly 29, no. 6 (March 1929): 225-26. Wallace produced many serious academic works. His tenure is outlined by Robert H. Blackburn in Evolution of the Heart: A History of the University of Toronto Library up to 1981 (Toronto: University of Toronto Library, 1989), 131-50.

10 Su Chen and Juming Zhao, "The Gest Chinese Research Library at McGill University, 1926-1936," East Asian Library Journal 11, no. 2 (2004): 41-99; and G. R. Lomer, “The University Library, 1920-1930," McGill News 11, no. 4 (September 1930): 7-11.

11 N. Merrill Distad, The University of Alberta Library: The First Hundred Years, 19082008 (Edmonton: University of Alberta Libraries, 2009), 23-51, details Cameron's tenure from 1921 to 1945.

12 Arthur Ford, "Fred Landon; Journalist, Librarian, Historian," Ontario Library Review [hereafter $O L R]$ 27, no. 2 (May 1943): 119-20. Landon was elected as a Fellow of the Royal Society of Canada in 1929.

13 Mary Ingraham, "The Bookmobiles of Acadia University," Library Journal 56 (January 1931): 62-63, and Tanja Harrison, "The Courage to Connect: Mary Kinley Ingraham and the Development of Libraries in the Maritimes," Library \& Information History 28, no. 2 (June 2012): 75-102. Ingraham was also known for her "grit:" Beatrice Shaw, "Maritime Librarian," Maclean's, November 15, 1924, 68-70.

14 Different reporting dates, internal inaccuracies or inconsistencies, building fires, and changing data definitions account for discrepancies in reported holdings.

15 Data compiled from the university chapter in Libraries in Canada (1933).

16 Philip J. Turner, "The University and College Libraries of Canada," Construction 24, no. 11 (November 1931): 358. However, space was greatly reduced because university administrators occupied most of the first and second floors until Richardson Hall was completed in 1954. 
17 Theodore D. Phillips, "The Mount Allison Libraries: A Brief History," in Hardiness, Perseverance and Faith: New Brunswick Library History, ed. Eric L. Swanick (Halifax: Dalhousie Library \& Information Studies, 1991), 139-46.

18 "New Library Opened," Toronto Globe, April 23, 1930, 13. Colonel Reuben Wells Leonard donated $\$ 100,000$ for this library.

19 John Leroux, Building a University: The Architecture of UNB (Fredericton: Goose Lane, 2010), 43-45, contains a blueprint of the entrance and principle façade.

20 King's notable holdings are described by Fenwick Vroom, King's College: A Chronicle 1789-1939 (Halifax: Imperial Publishing, 1941), 84-94.

21 Charles Johnston, McMaster University, Volume 2: The Early Years in Hamilton, 1930 1957 (Montreal and Kingston: McGill-Queen's University Press, 2015), 50-52.

22 Jean-René Lassonde, La Bibliothèque Saint-Sulpice, 1910-1931, 3rd ed. (Montréal: Bibliothèque nationale du Québec, 2001), 289-322.

23 For the early development of accepted standards for curricula and teaching in Canadian library education before 1940, see Peter McNally, "Fanfares and Celebrations: Anniversaries in Canadian Graduate Education for Library and Information Studies," Canadian Journal of Information and Library Science 18, no. 1 (April 1994): 7-11.

24 "Ontario Library Association, April 21 and 22, 1930," OLR 14, no. 4 (May 1930): 109. The index originated at Windsor Public Library in 1928.

25 This ALA regional group coordinated standard cataloguing procedures for university and large public libraries; it met frequently in Toronto until the early 1960s.

26 The section included librarians from large public libraries and emphasized helpful bibliographic and reference works that could be used by students, researchers, and staff.

27 E. C. Kyte, Queen's chief librarian, addressed eastern college delegates with a provocative theme, claiming students were receiving "text book degrees;" his address was published as "Colleges Fail," Columbia Spectator, November 30, 1936, 1. For his career, see William F. E. Morley, ed., Ernest Cockburn Kyte: A Tribute (Kingston: Douglas Library, 1970).

28 F. Landon, "Some Notes on the Bibliography of Canadian History," Papers of the Bibliographic Society of America 22, no. 1 (1928): 13-19.

29 Van Patten, a native New Yorker, was Queen's chief librarian from 1923-27 and went to Stanford University to be director of libraries from 1927-47.

30 Two UBC librarians made early contributions: Anne M. Smith, "Reference Resources of British Columbia," College \& Research Libraries 1, no. 1 (December 1939): 91-96, contributed to the first issue; Dorothy Chatwin, "Canadian Agricultural Documents, Federal and Provincial," C\&R Libraries 5, no. 1 (December 1943): 62-70.

31 “The New Victoria College Library Building, Toronto," Construction 4, no. 8 (July 1911): 54-62. Building grants were awarded to 108 American colleges from 1900-23.

32 See Ellen C. Lagemann, The Politics of Knowledge: The Carnegie Corporation, Philanthropy, and Public Policy (Chicago: University of Chicago Press, 1992), 110-15.

33 For the genesis of this group, see Neil A. Radford, The Carnegie Corporation and the Development of American College Libraries, 1928-1941 (Chicago: American Library Association, 1984), 19-24. Also see, Claud G. Sparks, Doyen of Librarians: A Biography of William Warner Bishop (Metuchen, NJ: Scarecrow Press, 1993).

34 F. P. Keppel, The Undergraduate and His College (Boston: Houghton Mifflin, 1917), 204-05. His ideas were shared by many, for example, Harold L. Leupp, "The Library, the Heart of the University," Bulletin of the American Library Association 18 (August 1924): 193-97, believed general recreational reading was deficient. Leupp headed the library at the University of California, Berkeley, from 1919-45.

35 William W. Bishop, "In Aid of College Libraries," Bulletin of the Association of American Colleges 16, no. 5 (May 1930): 290-97.

36 Radford, The Carnegie Corporation, 39-47. 
37 W. W. Bishop, Carnegie Corporation and College Libraries, 1929-1938 (New York: Carnegie Corporation, 1938), 26.

38 W. S. Learned and Kenneth Sills, Education in the Maritime Provinces of Canada (New York: Carnegie Foundation, 1922), 17-32.

39 Archibald MacMechan, "Canada as a Vassal State," Canadian Historical Review 1, no. 4 (December 1920): 350.

40 Keppel focused on the liberal arts college model for Canada. The American Carnegie program was much broader in scope: it included junior, teacher, black, state, and technological colleges.

41 For Commonwealth Carnegie projects, see Richard Glotzer, "Frederick P. Keppel and Carnegie Corporation's Interwar Area Experts: An Overview," American Educational History Review 33, no. 1 (2006): 47-56, and Maxine Rochester, "American Philanthropy Abroad: Library Program Support from the Carnegie Corporation of New York British Dominions and Colonies Fund in the 1920s and 1930s," Libraries \& Culture 31, no. 2 (Spring 1996): 342-63.

42 R. Lester, Memorandum of Interview with William W. Bishop, November 18, 1930. Carnegie Corporation of New York Archives, Columbia University, Grant Titles, Series III: A.I, box 3, folder 3, Advisory Group Canadian College Libraries, 1931-1937 (hereafter all citations in boxes 3 and 4 are abbreviated as AGCCL).

43 R. Lester, Memorandum of Interview with W. W. Bishop, January 21, 1930 and February 24-26, 1930, and letter from W. W. Bishop to R. Lester, May 9, 1931, AGCCL.

44 An 800-page printing of Shaw's compilation of 14,000 books was available for Canadian grant recipients: Charles B. Shaw, A List of Books for College Libraries, 2nd ed. (Chicago: American Library Association, 1931). His work was the first comprehensive identification of suitable college library books subdivided into broad academic disciplines.

45 See Malcolm MacLeod, A Bridge Built Halfway: A History of Memorial University College, 1925-1950 (Montreal and Kingston: McGill-Queen's University Press, 1990), for information on financial support and the career of Sadie Organ (BA, McGill), who was hired full-time as librarian in 1933 to organize the library. She received an $\$ 1,800$ ALA fellowship to earn an AMLS at Michigan in 1938 while on sabbatical leave.

46 Minutes of the Advisory Group Meeting held November 13, 1931, AGCCL.

47 Locke to Lester, March 8, 1932, AGCCL.

48 Gourlay Inspection Reports, June 1932. W. W. Bishop Papers, Carnegie Files, Advisory Group on College Libraries (Canada), box 16, folder 4, Bentley Historical Library, University of Michigan. Gourlay did not investigate campus departmental or faculty libraries.

49 The library was also used for dances: see James M. Pitsula, "Student Life at Regina College in the 1920s," in Youth, University and Canadian Society: Essays in the Social History of Higher Education, ed. Paul Axelrod and John G. Reid (Montreal and Kingston: McGill-Queen's University Press, 1989), 129.

50 No library responses were preserved in the AGCCL archive and minutes of meetings do not refer to the questionnaire.

51 Minutes of Advisory Group Meeting held June 28-29, 1932, AGCCL.

52 Bishop to Lester, July 27, 1932, and Lester's reply, August 1, 1932, AGCCL. Both men were determined that McGill would get a substantial grant.

53 Locke to Lester, July 30, 1932, AGCCL.

54 Detailed by Jim Blanchard, “The Machray Scandal," Manitoba History 33 (Spring 1997): 27-37.

55 G. R. Lomer, Report on a Proposed Three-Year Demonstration of Library Service for Prince Edward Island (Montreal: McGill University Library, 1932), 25-29. 
56 Lester to Locke, October 21, 1932, AGCCL.

57 Patterson had served on Brandon College's senate and board of governors prior to leaving for Acadia in 1923.

58 Keppel to Bishop, January 24, 1933, W. W. Bishop Papers (Michigan), box 16, folder 4.

59 "\$9,000 Gift to Dalhousie Library," and "Library Operates Under New Rules," Dalhousie Gazette, October 27, 1932, 1.

60 "Steps Towards New U.C. Library by Committee under Mr. Wallace," The Varsity, November 15, 1932, 1; and "Library Crowding Soon to be Relieved," The Varsity, January 16, 1933, 1. Details by W. S. Wallace, "New Library in the University College," University of Toronto Monthly 33, no. 8 (May 1933): 261-62. A law reading collection opened in the vacated main library space.

61 "The Carnegie Grant," Queen's University Journal, December 2, 1932, 2.

62 "Carnegie Corporation Recognizes Valuable Work of U.B.C. Library," The Ubyssey, November 4, 1932, 1 and 3.

63 “Grant of \$15,000 Made for McGill," Montreal Gazette, January 27, 1933, 3.

64 "New U. of T. Prize is Announced, and Relief of Library Crowding," Toronto Globe, January 14, 1933, 6.

65 Locke to Bishop, April 8, 1933, AGCCL.

66 For some reason not revealed by sources, the AGCCL did not recommend use of current bibliographies such as Toronto Public Library's Canadian Catalogue of Books, published annually after 1921, or compilations of publications in academic journals, such as the Canadian Historical Review. Possibly Locke was too busy collaborating with W. S. Wallace on a revised edition of $A$ Joint Catalogue of the Periodicals and Serials in the Libraries of the City of Toronto, published in 1934, to attend to a Canadian college bibliography.

67 Lester to Bishop, April 14, 1933, AGCCL.

68 Bishop to Lester, April 18, 1933, W. W. Bishop Papers (Michigan), box 16, folder 4.

69 Locke to Lester, April 27, 1933, AGCCL.

70 Lester to Locke, May 2, 1933 and June 8, 1933, AGCCL, "Notes and News: The American College," Library Association Record, Series 3, 3 (1933): 125-26.

71 "Varsity Library Inspected by Noted Ontario Librarians," The Manitoban, May 17, 1933, 1. According to Gourlay's report, Nuttall's standing was not unlike a janitor: W. W. Bishop Papers (Michigan), box 16, folder 4. Nuttall retired in 1937. His collection of Persian, Arabic, Turkish, and Hindi books and manuscripts is housed at the University of Michigan.

72 Memorandum of Interview, August 4, 1933, AGCCL.

73 Minutes of the Advisory Group, October 20, 1933, AGCCL.

74 Landon to Jones, April 20, 1933, University of New Brunswick, Cecil Charles Jones Presidents Papers, 1909 to 1945, UA RG 136, Series 3, 1931-1940, box 5, file 3.

75 One additional \$1,000 grant to St. Joseph's College, NB, was made in December 1933 bringing the total awards to $\$ 214,800$.

76 Regina united with Saskatchewan as a junior college in 1934 to offer the first year of a general BA. In 1935, Manitoba established a junior library for basic undergraduate needs on the second floor of the Administration Building at its Broadway site near the Legislature. The first library building designed specifically for undergraduate use in North America, the Lamont Library at Harvard, opened in 1949.

77 Appendix A, p. 4, Minutes of the Advisory Group, October 20, 1933, AGCCL.

78 Locke to Lester, December 7, 1934, AGCCL.

79 For all subsequent efforts to gauge the results of the American Advisory Group, see Radford, The Carnegie Corporation, 171-201. A major study conducted for the Association of American Colleges, funded by the CCNY, concluded that 
undergraduates did not make "very much use" of university or college library collections; see B. Harvie Branscomb, Teaching with Books (Chicago: American Library Association, 1940), 12-38.

80 See Michael J. Birkner, “'The Wisest Help': Frederick Keppel and his Consultants' Impact on Australia and New Zealand Libraries," Library \& Information History 29, no. 4 (November 2013): 258-71.

81 Although the key advisors were mostly men, Dr. Helen Stewart and Nora Bateson headed Canadian public library programs: see Maxine Rochester, "Bringing Librarianship to Rural Canada in the 1930s: Demonstrations by Carnegie Corporation of New York," Libraries \& Culture 30, no. 4 (Fall 1995): 366-90. Also, Jenny Collins, "Creating Women's Work in the Academy and Beyond: Carnegie Connections, 19231942," History of Education 38, no. 6 (November 2009): 791-808.

82 Quoted by Distad, University of Alberta Library, 41.

83 Report of the University Librarian to the Senate, 1934 (Vancouver: University of British Columbia, 1934), 3.

84 Letter of F. W. Patterson to Mary Ingraham, June 6, 1932, Acadia University, Mary Kinley Ingraham Collection (1944.001), Correspondence 1932-38, box 2, file 32.

85 "College and University Statistical Report, 4 Sept. 1935," and "Report to the President, 9 Aug. 1934," Ingraham Collection, Acadia materials, box 5, file 118.

86 For the various classification systems, see Survey of Libraries in Canada, 1935 (Ottawa: Dominion Bureau of Statistics, 1936), A19-A27. Bishop's hired a trained librarian and commenced using the Dewey classification system: "Bishop's University Given Grant of \$4,500," Montreal Gazette, April 3, 1933, 6.

87 Nathan Van Patten, "Co-Operative Cataloging in Canada," Library Journal 53 (April 1928): 353-55. Wallace's comment appears on p. 458.

88 Locke to UNB President Jones, April 29, 1933, Cecil C. Jones UNB Presidents' Papers, box 9 , file 3 .

89 See Distad, The University of Alberta Library, 53-79.

90 "Carnegie Grant Ends Soon," The Varsity, February 28, 1936, 1 and 4; Margaret V. Ray, "What Becomes of the University Woman? [1 and 2]," University of Toronto Monthly 30, no. 3 (December 1929): 95-96 and 30, no. 4 (January 1930): 135-38.

91 "Waterloo College Receives Carnegie Corporation Grant," The College Cord, October 29, 1932, 1. Snider was president of the Maritime Library Association, 1940-41.

92 H. C. Gourlay, "The Public Library and the College Graduate," OLR 20, no. 2 (May 1936): 66-68; and "Certification for Ontario Librarians," OLR 22, no. 3 (August 1938): 191-93.

93 Report of Informal Conferences On Library Interests, December 8, 1930, February 24, 1931, April 27, 1931 (New York: Carnegie Corporation, 1931), 13.

94 The merits and defects of Shaw's work are outlined in "Carnegie Grant Adds 'Balance' to U.B.C. Library," The Ubyssey, October 2, 1934, 1 and 3.

95 J. Ridington to Librarian, Acadia University, December 1932, Ingraham Collection, Correspondence 1932-38, box 2, file 33 .

96 Minutes of Carnegie Purchase Committee, December 7, 1932 and February 23, 1934, Victoria University, Library fonds, Series 2, Subject and Correspondence Files, Carnegie Fund 1932-36, box 5, file 22.

97 Letter of F. L. Barber to President Edward W. Wallace, November 12, 1934, box 5, file 22, Victoria University. Barber, a long-time professor at Victoria, headed the library from 1924-45.

98 "Report, June 1934," Annual Report, Memorial University College Library (St. John's, 1934), 2; and "Report, June 1935," 3.

99 "Queen's Library Thru' Grant Gets 1500 New Books," Queen's University Journal [hereafter QUJ], October 6, 1933, 1 and 7. 
100 E. C. Kyte's reply, QUJ, October 30, 1936, 7, to article "Library Lacks New Fiction," QUJ, October 23, 1936, 4.

101 "The Carnegie Grant," QUJ, October 11, 1933, 2; Paul Axelrod, "Moulding the Middle Class: Student Life at Dalhousie University in the 1930s," Acadiensis 15, no. 1 (Autumn 1985): 84-122; and P. Axelrod, Making a Middle Class: Student Life in English Canada During the Thirties (Montreal and Kingston: McGill-Queen's University Press, 1990), 231.

102 "Even Thomas Hardy Considered Improper," The Varsity, September 27, 1935, 1. Callaghan's They Shall Inherit the Earth was considered too risqué to be on Toronto's open shelves but was allowed to circulate by request.

103 The Almafilian (St. Thomas, ON: Alma College, 1934), 48.

104 "The Carnegie Library," Mc Gill Daily, December 13, 1933, 2 [editorial] and "Summer Reading," McGill Daily, March 12, 1934, 2.

105 A CCNY grant was used by Peyton Hurt, The University Library and Undergraduate Instruction (Berkeley: University of California Press, 1936) to explore services for independent undergraduate study and relationships with faculty.

106 For example, John Ridington's Report of the University Librarian to the [UBC] Senate, October 1928, 13, urging formal courses; and "E. C. Kyte Conducts Tour Through Library," QUJ, October 2, 1934, 4.

107 C. Cameron Waller, "The Need of Training Students to Use the Library," OLR 15, no. 1 (February 1931): 92-93; and Catherine Campbell, "Introducing the Student to the University Library," OLR 15, no. 2 (May 1931): 110-12.

108 Beatrice Welling and Catherine Campbell, Library Science for Canadians (Toronto: Pitman \& Sons, 1936). Co-author Catherine Campbell was a long-time Western instructor and oversaw three editions of this work to 1958.

109 "Inquiry Desk Installed to Aid Essay Writing," QUJ, November 2, 1934, 1 and 4.

110 Recounted by R. Blackburn, Evolution of the Heart, 143-44. Annie Hester Young (BA, University of Toronto, 1896) was the head cataloguer at Toronto for many years. She trained at the Pratt Institute Library School in 1902 and the McGill summer library school in 1904.

111 For example, Western's Department of Library Science bachelor's major was discontinued in 1928 and thereafter library courses were linked with the Department of Secretarial Science program.

112 "Report of the Library Committee" in President's Report, Memorial University College, 1936-37 (St. John's: Memorial University College, 1937), [p. 2] dated June 9, 1937.

113 “A Library ... or a Nursery?" Mc Gill Daily, March 7, 1935, 2.

114 "Wallace Willing to Extend Hours If Demanded," The Varsity, March 11, 1937, 1 and 4.

115 Report of the University Librarian to the Senate [for April 1934 to March 1936], Feb. 1937, 30-33.

116 F. Landon, "Lawson Memorial Library," OLR 19, no. 3 (August 1935): 118-120.

117 "The University Library," The Xaverian (Antigonish: St. Francis Xavier University, May 1934), 49.

118 Hugh Gourlay's reports on individual libraries and the conditions imposed by the AGCCL provide an important historical record of university library development before the Charles McCombs Report for the Rockefeller Foundation in 1941. McCombs' survey of research libraries is reproduced in Buxton and Acland, American Philanthropy and Canadian Libraries.

119 Mary C. Macdonald, "The Relation of the Library to the Co-Operative Movement of St. Francis Xavier," Bulletin of the Maritime Library Institute 2, no. 1 (June 1937): 2-3; Anne M. Smith, "The House That Jack May Build: Canadian University Libraries and Postwar Rehabilitation,” Wilson Library Bulletin 19, no. 3 (November 1944): 185-87. 